\section{NEW POPULATION OF CyCAS SPHAERICA ROXB. (CYCADACEAE) DISCOVERED IN PINJARIKONDA Reserve Forest, ANDHRA PRADESH, INDIA}

\author{
J. Prakasa Rao ${ }^{1}$, M. Ravi Kumar ${ }^{2}$, V. Satya \\ Ramachandra Rao ${ }^{3}$, O. Aniel Kumar ${ }^{4}$ \& M. Venkaiah ${ }^{5}$ \\ 1,4,5 Department of Botany, Andhra University, Visakhapatnam, \\ Andhra Pradesh 530003, India \\ ${ }^{2,3}$ Department of Botany (P.G.), V.S.M. College, Ramachandrapuram, \\ East Godavari District, Andhra Pradesh 533255, India \\ ${ }^{1}$ jprakasarao@gmail.com (corresponding author), \\ ${ }^{2}$ ravimkumar28@gmail.com, ${ }^{3}$ smartsathyam@yahoo.com, \\ ${ }^{4}$ owkanielkumar@yahoo.com, ${ }^{5}$ venkaiah_botany@rediffmail.com
}

Cycas is a single genus of the family Cycadaceae consisting of 100 species. It is the sole living cycad group occurring in Asia (Lindstrom \& Hill 2007). Nine taxa, namely, C. beddomei Dyer, Trans., C. circinalis L., C. indica Lindstrom \& Hill, C. sphaerica Roxb., C. annakailensis R. Singh \& P. Radha, C. nathorstii J. Schust., C. pectinata Buch.-Ham. C. zeylanica (J. Schust.) A. Lindstrom \& K.D. Hill and $C$. swamyi Singh \& Radha are reported in India (Lindstrom \& Hill 2007; Singh \& Radha 2008; Singh \& Singh 2011); two species C. swamyi Singh \& Radha and C. annakailensis R. Singh \& P. Radha are considered synonyms of $C$. circinalis L. and C. sphaerica Roxb., respectively (Ranjay et al. 2010), hence seven species are presently recognized in India. C. sphaerica was first mentioned by Roxburgh in 1814, and described in 1832 (Lindstrom \& Hill 2007). As reported by Raju in (2006) C. sphaerica Roxb. is morphologically similar to C. circinalis L. in most respects but differs in certain characters such as megasporophyll structure.

C. sphaerica Roxb. is endemic and distributed along the hilly tracts of Eastern Ghats of northern Andhra Pradesh, Odisha, Tamil Nadu and Karnataka (Reddy et al. 2007; Varghese \& Krishnamurthy 2010). In Andhra Pradesh, it is found occasionally in dry deciduous forests in northernmost part of Srikakulam District and woodlands

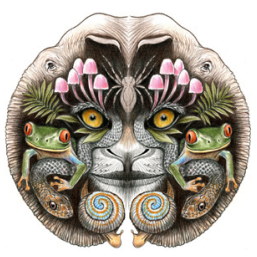

ISSN

Online 0974-7907 Print 0974-7893

\section{OPEN ACCESS} of Palakonda, Donubayi and Seetampet areas (Reddy et al. 2007). A population of more than 500 trees exists at Jalanthrakota Reserve Forest in the low elevation deciduous forest in Srikakulam District (Raju et al. 2009). In Odisha, these are occasionally found in the woodlands of Gajapathi, Ganjam, Khurda, Cuttack and Dhenkanal districts; sparse in moist deciduous forests of Phulbani, Boudh, Nayagarah, Angul, Keonjhar and Mayurbhanj districts (Reddy et al. 2007). In the flora of Srikakulam District it was mentioned under the name of C. circinalis L. (Rao \& Sreeramulu 1986). It is listed in IUCN as Data Deficient and is included in CITES Appendix II (Varghese \& Krishnamurthy 2010).

In Eastern Ghats there are three Cycas species among which C. beddomei, is endangered (Rao 2010), a global endemic species and known only from Seshachalam Hills in Andhra Pradesh. C. circinalis L. is restricted to the Western Ghats and some parts of Eastern Ghats in Andhra Pradesh and Tamil Nadu.

Pinjarikonda Reserve Forest (2282.90ha) is located between $17^{\circ} 26^{\prime}-17^{\circ} 28^{\prime} \mathrm{N} \& 81^{0} 59^{\prime}-82^{\circ} 01^{\prime} \mathrm{E}$ Eastern Ghats in East Godavari District, Andhra Pradesh, India (Fig. 1). The forest located in Addateegala (452.82ha) and Sudikonda (1830.08ha) forest ranges a perennial stream of the Pinjarikonda waterfall flowing along the forest. Elevation range is from 100-456 m. Red sandy soil, khondalite type rocks are present in the study area.

DOI: http://dx.doi.org/10.11609/JoTT.03370.5871-4

Editor: Ravi Prasad Rao, Sri Krishnadevaraya University, Anantapur, Andhra Pradesh.

Date of publication: 26 June 2014 (online \& print)

Manuscript details: Ms \# 03370 | Received 22 June 2013 | Final received 23 May 2014 | Finally accepted 27 May 2014

Citation: Rao, J.P., M.R. Kumar, V.S.R. Rao, O.A. Kumar \& M. Venkaiah (2014). New population of Cycas sphaerica Roxb. (Cycadaceae) discovered in Pinjarikonda Reserve Forest, Andhra Pradesh, India. Journal of Threatened Taxa 6(6): 5871-5874; http://dx.doi.org/10.11609/JoTT.o3370.5871-4

Copyright: (C) Rao et al. 2014. Creative Commons Attribution 4.0 International License. JoTT allows unrestricted use of this article in any medium, reproduction and distribution by providing adequate credit to the authors and the source of publication.

Funding: None.

Competing Interest: The authors declare no competing interests.

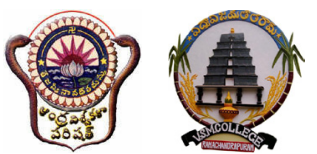

Acknowledgements: Authors are thankful to forest range officers in Sudikonda and Addateegala forest ranges, also grateful to local people for their help during field studies and in the collection of plant materials. 
Vegetation type is the tropical dry deciduous forest.

The overall population size of $C$. sphaerica Roxb. is not known (Varghese \& Krishnamurthy 2010). Detailed survey and documentation of geographical distribution of the native cycad taxa, their pests and diseases is urgently needed (Muniappan \& Virakatamath 2006). Endemic plants are more prone to extinction for various reasons as they are habitat specific. Because of unstable habitats, in a small area with a limited population they are extra stressed. Therefore, such endemics must be prioritized for conservation efforts (Rawat 2009). Indian cycads are threatened largely as a result of human activities (Singh \& Singh 2011).

Materials and Methods: C. sphaerica Roxb. specimens were collected and observed during the period of April 2010 to June 2011 from Pinjarikonda Reserve Forest and identified with the help of the floras and literature (Lindstrom \& Hill 2007; Reddy et al. 2007) at the time of our explorations in East Godavari District. The voucher specimen (AU (B.D.H.) JPR-20298) is deposited at the Herbarium of Botany Department, Andhra University.
Results: Cycas sphaerica Roxb. Fl. Ind.: 747 (1832). Type: ex hort. Calcutta, Roxburgh s.n., 1808 (lecto BM, fide Hill 1995). C. circinalis var. orixensis Haines, Bot. Bihar Odisha 6: 1228 (1924). Type: India, Odisha, Mals of Puri, Haines 5876, June 1917 (syn. K); Angul, Haines 5877, July 1917 (syn. K). C. annakalensis Singh \& Radha, Brittonica 58.119.2006. (syn. now).

Small palm like tree up to $5 \mathrm{~m}$ tall, dioecious (Image $1 \mathrm{c}, \mathrm{j})$, usually female plants posses branches, stems are arborescent with a girth up to $135 \mathrm{~cm}$. Bark is thick with alternate bands of scars on persistent leaf bases and cataphylls. Leaves are pinnate, dark green, semiglossy, 95-160 cm, leaflets 55-215 and are generally produced in the season before cone formation. The median leaflets are simple, weakly discolored, they are 13-21 $\mathrm{cm}$ long and 7-12 $\mathrm{mm}$ wide with a soft acuminate apex. Cataphylls are narrowly triangular soft, thinly sericeous or lacking tomentum. Usually cones are formed from May to August. Male cones are orange colored, narrowly ovoid with spirally arranged numerous dorsiventral microsporophylls (Image $1 \mathrm{~d}$-i). Female cones are loosely packed with megasporophylls.

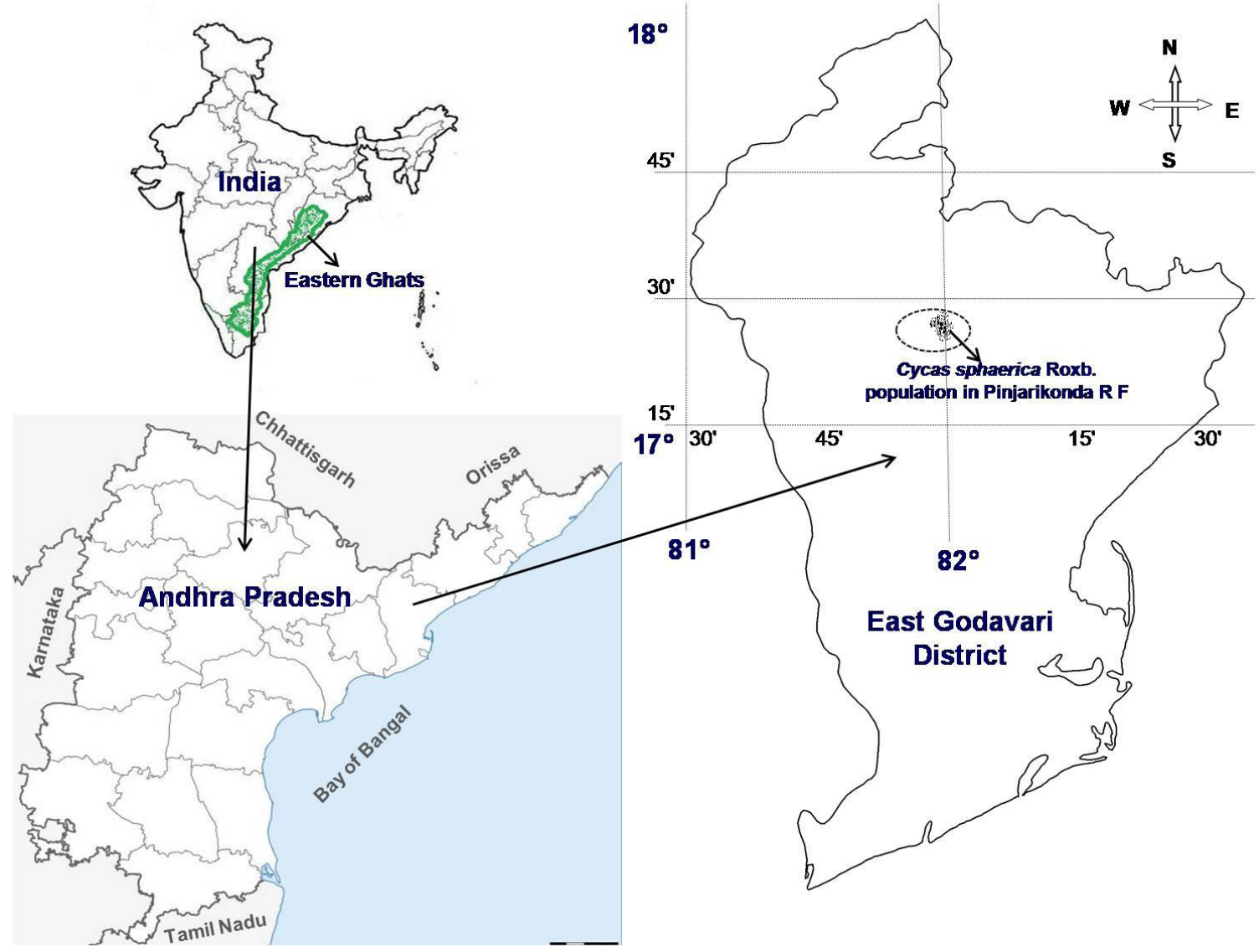

Figure 1. Location map of Cycas sphaerica Roxb. in the study area 

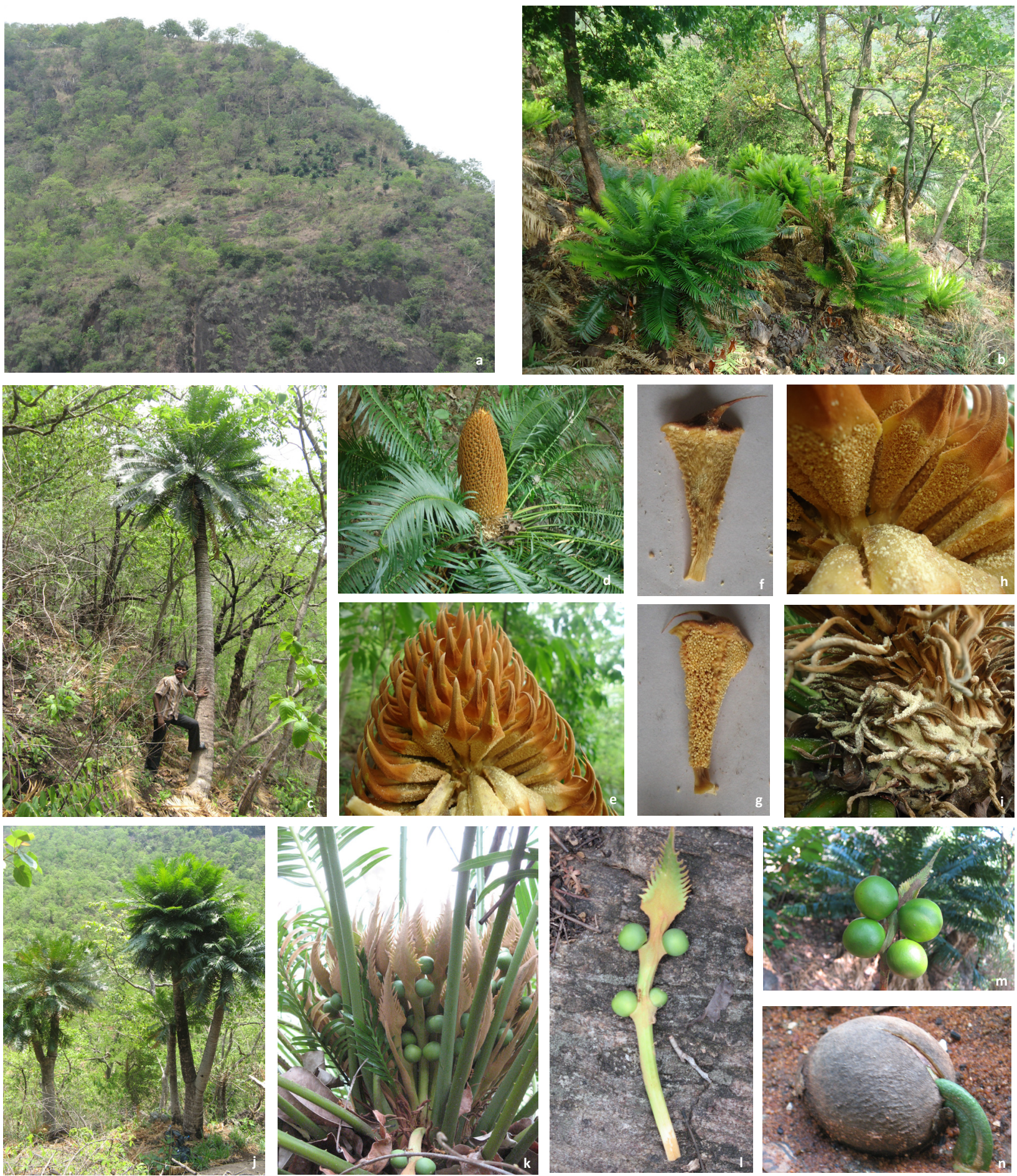

Image 1. a-b - Cycas sphaerica Roxb. habitat in the study area; c - Male plant; d - Male cone; e - Opened male cone; $f$ - Microsporophyll upper surface; $g$ - microsporophyll lower surface with sporangia; $\mathbf{h}$ - Dehisced sori; $\mathbf{i}$ - Pollen grain powder; $\mathbf{j}$ - Female plants; $\mathbf{k}$ - Opened female cone; I - Mega sporophyll with ovules; $\mathbf{m}$ - seeds on mega sporophyll; $\mathbf{n}$ - germinating seed. (c) J. Prakasa Rao

Megasporophylls are $20-25 \mathrm{~cm}$ long, lamina lanceolate, apical spine distinct from lateral spines, persistently orange-tomentose with four glabrous ovules (Image 1 k,l). Matured seeds are subglobose or globose (Image 1 $m, n$ ) with yellow sarcotesta, sclerotesta smooth.

Populations of 700 individuals were observed in Painjarikonda Reserve Forest at Pinjarikonda waterfall (Image $1 \mathrm{a}, \mathrm{b}$ ). Aged individuals were found scattered on 
the hill top of Potulakonda Hill at an altitude of $456 \mathrm{~m}$, while young and newly emerging individuals were found along the stream bank of Pinjarikonda waterfall beside the Potulakonda Hill. C. sphaerica Roxb. is locally called 'Kodada chettu', because of this reason Potulakonda Hill is also called 'Kodadakonda'. This is the second distribution record from Andhra Pradesh.

Some threats like forest fire, collection of male cones and collection of tender leaves were observed in the location. Tender leaves are used as a leafy vegetable and male cones are placed in their house, it is believed to protect their families from evil spirits.

Discussion: From East Godavari District one or two Cycas plants were observed by Rolla Seshagiri Rao in 1947 along the dense forest and reported as C. circinalis L. from Maredumilli and Dummakonda areas (Rao et al. 1999). There is no information on Cycas sphaerica Roxb. from the study area, this is the first distributional record form the East Godavari District. Distribution of this species from the Eastern Ghats of Andhra Pradesh and Odisha was reported by Singh \& Singh (2011). Present exploration enhances the distributional area of this species in Andhra Pradesh (Fig. 1).

Conclusions: The present habitat of $C$. sphaerica Roxb. has provided extended distribution of this species in the Eastern Ghats of Andhra Pradesh. This species may be present in other localities of the East Godavari District, so further studies need to be carried out with concerns on distribution, population size and threats to the habitat in the present location as well as other areas of the Eastern Ghats where it is available. The present location Pinjarikonda Reserve Forest is the suitable for in situ conservation of this species and investigate the need to introduce this species into the botanical gardens for ex situ conservation practices.

\section{References}

Lindstrom, A.J. \& K.D. Hill. (2007). The genus Cycas (Cycadaceae) in India. Telopea 11(4): 463-488.

Muniappan, R. \& C.A. Viraktamath (2006). The Asian Cycad Scale Aulocaspis yasumatsui, a threat to native cycads in India. Current Science 91: 168-170.

Raju, A.J.S. (2006). Ecology and conservation aspects of endemic and endangered Cycas species in the Eastern Ghats. ENVIS-SDNP Newsletter, Special Issue p.7.

Raju, A.J.S. \& K.H. Jonathan (2010). Anemophily, accidental cantharophily, seed dispersal and seedling ecology of Cycas sphaerica Roxb. (Cycadaceae), a data-deficient red-listed species of northern Eastern Ghats. Current Science 99: 1105-1111.

Raju, A.J.S., K.S. Rao \& N.G. Rao (2009). Association of Indian Stingless Bee, Trigona iridipennis Smith (Apidae: Meliponinae) with Redlisted Cycas sphaerica Roxb. (Cycadaceae). Current Science 96: 1435-1436.

Ranjay, K.S., R.C. Srivastava \& T.K. Mukherjee (2010). Three bioculturally important gymnosperms of India. Indian Journal of Traditional Knowledge 9(3): 430-431.

Rao, B.R.P. (2010). Cycas beddomei. In: IUCN 2013. IUCN Red List of Threatened Species. Version 2013.1. <www.iucnredlist.org>. Downloaded on 05 July 2013.

Rao, R.S. \& S.H. Sreeramulu (1986). Flora of Srikakulam District, Andhra Pradesh, India. Indian Botanical Society, Meerut, 640pp.

Rao, R.S., S. Sudhakar \& P. Venkanna (1999). Flora of East Godavari District. INTACH, A.P. State Chapter, Hyderabad, 947pp.

Rawat, D.S. (2009). A presumed extinct endemic alpine herb Gentiana tetrasepala rediscovered after 123 years: will it survive? National Academy Science Letters 32: 169-172.

Reddy, C.S., K.S. Rao, C. Patanaiak, K.N. Reddy \& V.S. Raju (2007). Cycas sphaerica Roxb. A little known endemic species from Eastern Ghats, India. Journal of Plant Sciences 2(3): 362-365.

Singh, R. \& K.J. Singh (2011). The importance of Odisha Cycas in India. Biodiversity 12(1): 21-27; http://www.dx.doi.org/10.1080/148883 86.2011.574424

Singh, R. \& P. Radha (2008). A new species of Cycas (Cycadaceae) from Karnataka, India. Botanical Journal of the Linnean Society 158: 430435; http://www.dx.doi.org/10.1111/j.1095-8339.2008.00924.x

Varghese, A. \& V. Krishnamurthy (2010). Cycas sphaerica. In: IUCN 2013. IUCN Red List of Threatened Species. Version 2013.1. <www. iucnredlist.org>. Downloaded on 05 July 2013. 